Ecotoxicology

March 2017, Volume 26, Issue 2, Pages 165-172

http://dx.doi.org/10.1007/s10646-016-1751-6

http://archimer.ifremer.fr/doc/00371/48225/

(c) Springer Science+Business Media New York 2016

\title{
Use of low density polyethylene membranes for assessment of genotoxicity of PAHs in the Seine River
}

\author{
Vincent-Hubert Françoise ${ }^{1,2,{ }^{*}}$, Uher Emmanuelle ${ }^{1}$, Di Giorgio Carole ${ }^{3}$, Michel Cécile ${ }^{1}$, \\ De Meo Michel ${ }^{3}$, Gourlay-France Catherine ${ }^{1}$
}

1 IRSTEA, UR Hydrosystèmes et BioprocédésAntony cedex,France

2 IFREMER, Laboratoire de Microbiologie - LNR, rue de l'île d'YeuNantes,France

${ }^{3}$ Biogénotoxicologie et Mutagenèse Environnementales (EA 1784)Université de la MéditerranéeMarseille, France

* Corresponding author : Françoise Vincent-Hubert, email address : francoise.vincent@ifremer.fr

\begin{abstract}
:
The genotoxicity of river water dissolved contaminants is usually estimated after grab sampling of river water. Water contamination can now be obtained with passive samplers that allow a time-integrated sampling of contaminants. Since it was verified that low density polyethylene membranes (LDPE) accumulate labile hydrophobic compounds, their use was proposed as a passive sampler. This study was designed to test the applicability of passive sampling for combined chemical and genotoxicity measurements. The LDPE extracts were tested with the umu test (TA1535/pSK1002 \pm S9) and the Ames assay (TA98, TA100 and YG1041 \pm S9). We describe here this new protocol and its application in two field studies on four sites of the Seine River. Field LDPE extracts were negative with the YG1041 and TA100 and weakly positive with the TA98 + S9 and Umu test. Concentrations of labile mutagenic PAHs were higher upstream of Paris than downstream of Paris. Improvement of the method is needed to determine the genotoxicity of low concentrations of labile dissolved organic contaminants.
\end{abstract}

Keywords : Genotoxicity, River water, Passive samplers, PAHs, Ames assay, Umu test 
Water pollution by chemicals as a result of industrialization and increasing urbanization is a factor that

threatens the preservation of aquatic ecosystems and also human health. Polycyclic Aromatic

Hydrocarbons (PAHs) constitute a ubiquitous class of environmental chemical pollutants identified in

surface waters and sediments. Many of them are mutagenic and can impact aquatic organisms (Ohe

et al., 2004). Most studies report the mutagenic activity of dissolved and particulate PAHs after grab

sampling of large volumes of water. As a consequence, the genotoxicity of river waters or effluents could be either underestimated or overestimated, depending upon the recent discharge of pollutants into the river water.

More representative information of water contamination can now be obtained with passive samplers that allow a time-integrated sampling of contaminants (Lebo et al., 1992; Vrana et al., 2005). Once immersed, passive sampler devices accumulate contaminants from the water. For dissolved hydrophobic contaminants, a semi-permeable membrane device (SPMD) was developed in the 1990's. The low density polyethylene (LDPE) membrane has been also proposed as a passive sampler as it has been confirmed that it can accumulate dissolved hydrophobic compounds that are bioavailable to some aquatic organisms (Booij et al., 2003; Carls et al., 2004; Gourlay et al., 2005). As a single-phase sampler, LDPE has been gaining interest because it avoids the toxicity of triolein, a molecule contained in the lipidic phase of SPMD (Sabaliunas et al., 1999). been performed to determine the limits of this coupling. Regarding SPMDs, it has been shown that oleic acid derived from triolein induces a positive response in bioassays (Sabaliunas et al., 2000). Presently, no data are available for LDPE membranes and their release of compounds when immersed 
contaminants by adsorbing them during the bioassay, and thus lower the response of the bioassay.

70 The impact of purification procedures on the test response needs to be evaluated.

In France, evidence of mutagenic activities have been demonstrated in the water column and

in the sediment of the Seine estuary. Suspended particulate matter collected downstream of various petrochemical industries was positive with the Ames assay (TA98+S9) and the comet assay (HepG2+S9) and sediment from the estuary was also genotoxic and mutagenic (Cachot et al., 2006; Vincent-Hubert et al., 2012). The principal sources of pollution in the Seine River basin come from high industrial and urban activities and intensive agriculture. This area of France $(75,000 \mathrm{~km} 2)$ is inhabited by about 16 million people, concentrated within the Paris area. This population density leads to elevated levels of pollutants in water, including PAHs (Blanchard et al., 2007; Meybeck et al., 2007; Tusseau-Vuillemin et al., 2007). However, the mutagenicity of surface water contaminants from the Paris area has not been reported. genotoxic contaminants in surface water, wastewater and industrial effluents (Ohe et al., 2004). Most of the published studies employed the Salmonella typhimurium mutagenicity test with strains TA98 and/or TA100, with and without metabolic activation (S9 mix). Data obtained with the Salmonella strains can provide information on the classes of mutagens present in the water. For example, the YG1041 strain is more sensitive to nitroaromatic compounds than the parent strain TA98 (Watanabe et al., 1989). Nitro-PAHs have been detected in the extracts of environmental materials containing diesel emissions and in urban river waters (Murahashi et al., 2001). The umu test was developed as an alternative to the Ames test by Oda (Oda et al., 1985). Activation of the SOS repair system by genotoxic compounds is measured by photometric determination of the $\beta$-galactosidase enzyme activity. The umu test is widely used for routine monitoring of water samples as the results are available in a single day with minimal advance preparation. The umu test proved to be very sensitive for the detection of mutagens in surface waters in Germany and Japan (Dizer et al., 2002; Ohe, 1996). 
96 with genotoxicity assays. The umu test was chosen as a pre-screening test for its capacity of induction

97 of the SOS-system. For the Salmonella mutagenicity assay, three strains were chosen, the TA 98, TA

98100 and YG1041 strains. Two field applications of the developed protocol are presented here. In the

99 urban area of Paris, LDPEs were deployed for three weeks in two different years at four river sites,

100 then genotoxicity testing and chemical analyses of LDPE extracts were performed.

101

102 


\subsection{Chemicals}

106 Dimethylsulfoxide (DMSO) for molecular biology, 4-nitroquinoline-1-oxide (4NQO), 1-nitropyrene (1-

$107 \mathrm{NP}$ ), chlorophenol red- $\beta$-D-galactopyranoside (CPRG), sodium azide (SA), 2 aminoanthracene, and 108 benzo[a]pyrene (BaP) were purchased from Sigma (France). Rat S9 was from Trinova (Germany).

109 Heptane Picograde ${ }^{\circledR}$ for residue analysis was purchased from LGC Promochem (France) and ethyl 110 acetate Suprasolv ${ }^{\circledR}$ for Gas Chromatography from VWR (France).

\subsection{Preparation and deployment of LDPE membranes}

113 Pieces $(10 \times 30 \mathrm{~cm})$ of LDPE membranes (membrane thickness of $80 \mu \mathrm{m}$ ) were cut from a roll (Manutan,

114 France). A cleaning procedure was performed to avoid the potential effects of impurities contained in

115 LDPE membranes, as preliminary tests revealed a slight toxicity of non-cleaned LDPE. This procedure

116 consisted of immersing LDPE sheets into a heptane/ethyl acetate mix (50/50, v/v) twice for $24 \mathrm{~h}$ each.

117 The solvents were refreshed after the first 24-h period. LDPE sheets were then rinsed by immersion in

118 ultrapure water for 12 days to remove solvent traces. Water was changed every four days. A

119 preliminary three weeks field deployment study, on contaminated river sites, revealed that LDPE 120 extracts were genotoxic in the umu test in these conditions (data not shown).

\subsection{Field studies}

123 Four river sites were selected for the deployment of four LDPE membranes per site at $1.50 \mathrm{~m}$ depth

124 (Fig.1). One river site was not impacted by the urban activity of Paris (Marnay-sur-Seine) and the three 125 others were highly impacted by the urban area of Paris: Saint-Maurice, Triel-sur-Seine and Bougival. 126 Bougival is also impacted by the Seine-Aval wastewater treatment plant (Blanchard et al., 2007; 127 Meybeck et al., 2007; Tusseau-Vuillemin et al., 2007). Two field studies were performed, the first one, 
in spring 2009, was limited to Marnay-sur-Seine and Bougival, and the second one was conducted on

129 the four sites during the spring and autumn 2010.

130

\section{$131 \quad 2.4$ Extraction and purification of the PAHs}

133 After field deployment, membranes were thoroughly cleaned of biofilm. They were then immersed in

$134250 \mathrm{ml}$ heptane/ethylacetate mix (50/50) in closed amber glass bottles. Bottles were stirred on an

135 orbital shaker at $100 \mathrm{rpm}$ for $48 \mathrm{~h}$. A preliminary study showed that 94 to $99 \%$ of the compounds were

136 removed from the membranes with this procedure. Membranes were then removed from the solvent

137 extract. The solvent mix was reduced to $1 \mathrm{~mL}$ with a rotary evaporator. The extract was purified with

138 a florisil column (Phenomenex, France) pre-conditioned with $5 \mathrm{~mL}$ of $94 / 6$ heptane/ethylacetate mix.

139 Elution was performed by transferring $4 \times 5 \mathrm{~mL}$ of a $94 / 6$ heptane/ethylacetate mix. Solvent was

140 evaporated under a gentle steam of $\mathrm{N}_{2}$. The evaporation was stopped when a $1 \mathrm{~mL}$ volume was

141 reached: $200 \mu \mathrm{L}$ were reserved and spiked with the internal standards mix (Naphtalene-d8;

142 Acenaphtalene-d10; Phenanthrene-d10; Chrysene-d12; Perylene-d12) and stored at $-20^{\circ} \mathrm{C}$ for chemical

143 analysis. The last $800 \mu \mathrm{L}$ were evaporated until near dryness $(5 \mu \mathrm{l})$ and transferred into $200 \mu \mathrm{L}$ of DMSO

144 for genotoxicity testing.

\section{$146 \quad 2.5$ Chemical analysis of LDPE}

147 PAH analyses were performed on a GC/MS (Thermo electron, Les Ulis, France) operating in Selected

148 Ion Monitoring mode. The ionisation mode was electronic impact and the analyser was a simple

149 quadrupole. It was equipped with a Zebron ZB-5MS capillary GC column (60 m length x 0,25 mm ID x

$150 \quad 0.2 \mu \mathrm{m}$ film thickness). PAHs were quantified with internal calibration. The target PAHs were those on

151 the US EPA list (fluoranthene, fluorene, anthracene, benzo(b)fluoranthene, benz(a)anthracene,

152 indeno(1,2,3-cd)pyrene, benzo(a)pyrene, dibenzo(a,h)anthracene, benzo(g,h,i)perylene,

153 phenanthrene, benzo(k)fluorothene, pyrene and chrysene) excluding the three with lowest molecular 
154 weights (naphthalene, acenaphtylene, acenaphtene). Detection limits were $10 \mathrm{ng} \cdot \mathrm{L}^{-1}$ in the final 155 extract for each PAH.

156

\subsection{Matrix effect}

158 Non-deployed LDPE membranes were extracted as blank extracts. These blank extracts were spiked with the reference genotoxic components 1-NP and BaP. The umu test and Ames test were performed with these spiked extracts.

\section{7 umu test}

163 The genotoxicity of PAHs accumulated on LDPE membranes was assessed with the umu-microplate

164 test using the bacterial strain TA1535/pSK1002 according to Oda (2004) and slightly modified by using Chlorophenol red-D-galactopyranoside (CPRG $(4 \mathrm{mg} / \mathrm{ml}$ ) instead of $O$-nitrophenyl- $\beta$-D

166 galactopyranoside (Oda et al., 2004). The cytotoxic effect of the samples was determined by measuring

$167 \mathrm{OD}_{600 \mathrm{~nm}}$ changes and the genotoxic effects were evaluated by $\mathrm{OD}_{570 \mathrm{~nm}}$ changes. Samples with a growth 168 ratio $(G)<0.8$ were considered cytotoxic and samples with an induction ratio $($ IR) $>1.5$ were considered

169 to be genotoxic (Dizer et al., 2002). Determination of growth factor G, relative enzyme activity (REA)

170 and induction rate (IR) were calculated as described in Oda et al (.2004). The results are presented as

171 the mean \pm SD of two or three independent experiments. Because most PAHs required metabolic 172 activation to be genotoxic, an activation system was used containing S9 of rats ( $4 \% \mathrm{~S} 9,0.4 \mathrm{M} \mathrm{MgCl}$, $1731.65 \mathrm{M} \mathrm{KCL}, 1.0 \mathrm{M}$ Glucose 6-Phosphate, 0.1 M NADPH, 0.1 M NADH, and 0.2 M Na-Phosphate buffer $174 \mathrm{pH}$ 7.4). Final concentrations of positive controls were: $4 \mathrm{NQO}(0.132 \mu \mathrm{M}), 1 \mathrm{NP}(0.8 \mu \mathrm{M})$ and BaP $(5$ $175 \mu \mathrm{M}$ ) with S9 mix. 
180 The mutagenicity of PAHs extracted from LDPE membranes was assessed by the microsuspension

181 version of the Salmonella mutagenicity test (De Méo et al., 1995) using three strains of Salmonella 182 typhimurium, strains TA98, TA100 and YG1041. TA98 has been shown to detect PAHs in the presence 183 of S9 mix (De Méo et al., 1995) (Nikoyan et al., 2007). N-heterocyclic or aromatic amines have shown 184 elevated mutagenic activities in the presence of S9 mix on the metabolically enhanced YG1041 that expresses $O$-acetyl transferase (Hagiwara et al., 1993). Nitroarenes have displayed a high mutagenic activity without metabolic activation in the nitroreductase-enhanced YG1041 strain (Nikoyan et al., 187 2007).

188 Each experiment included triplicate plates of four tested doses $(4,6,8$ and $10 \mu \mathrm{L})$. A solvent (DMSO) 189 control was added to detected the spontaneous frequency of revertants (quadruplate plates). Two 190 positive controls were also included to ensure the performance of the tester strains and the S9 Mix: $19120 \mathrm{ng} /$ plate 2,4,7-trinitrofluorenone (TNFone) for TA98 and YG1041 and $5 \mu \mathrm{g} /$ plate sodium azide for 192 TA100, 0.5 and $1.0 \mu \mathrm{g} / \mathrm{plate}$ of BaP for TA98 and YG1041 with S9 Mix.

193 A two-step analysis was performed to interpret data. The Dunnett test (Wahrendorf et al., 1985) was

194 performed to determine the significance of differences between the mean number of induced 195 revertants and the mean number of spontaneous revertants. If the Dunnett test was positive for at 196 least one tested concentration, non-linear regression analysis was carried out using two arbitrary 197 models as described previously (Kim and Margolin, 1999) with Table Curve $2 \mathrm{D}^{\circ}$ software (version 5.0, 198 Jandel Scientific Software, San Rafael, CA, USA):

199 MAR-1: rev / plate $=(\mathbf{a}+\mathbf{b} * \mathbf{D}) *\left(2-\mathbf{e}^{\left(\mathbf{c}^{*} \mathbf{D}^{2}\right)}\right)$ and MAR-2: rev / plate $=(\mathbf{a}+\mathbf{b} * \mathbf{D}) * \mathbf{e}^{\left(-\mathbf{c}^{*} \mathbf{D}^{2}\right)}$

200 With: rev/plate: number of revertants by plate 


\section{Results}

Preliminary tests performed to develop the coupling of mutagenicity tests and passive sampling. No matrix effect of LDPE membranes was detected in our experimental conditions (data not shown) indicating that molecules from LDPE membranes did not modify the genotoxity of BaP.

Two field studies were conducted, the first one in 2009 and the second in 2010. Samples obtained in 2009 did not present any genotoxicity in the Umu test, with or without metabolic activation (Table 1). As we did not have enough LDPE extracts, we tested them on TA98+S9 and YG1041+S9 only, which are more sensitive to mutagenic activity of PAHs, a class of contaminants predominant in urban areas. The sample from Marnay-sur-Seine site was statistically mutagenic in the Ames test (TA 98+S9) (Table 1), indicating the presence of frameshift mutagens. No mutagenic activity was detected with YG1041, indicating that no nitroaromatic compounds were present in these extracts.

For samples obtained in 2010 , only one sample, Bougival, was positive in the umu test, indicating the presence of direct acting genotoxic compounds in the river water there (Table 2). All samples displayed statistically significant mutagenic activity in the Ames test (TA98 with S9 mix) (Table 2) indicating the presence of frameshift mutagens in the river water at the four sites and for both seasons; two out of eight samples were statistically mutagenic (TA98 without S9 mix) indicating the presence of direct frameshift mutagens at Marnay-sur-Seine and Saint-Maurice. No mutagenic activity was detected with the TA100 with or without S9 mix indicating the absence of mutagens inducing base substitutions.

The concentrations of total labile PAHs in LDPE measured in the 2010 samples shown that the Marnaysur-Seine site was the least contaminated and the Bougival and Triel-sur-Seine sites were the most contaminated (Table 3). The highest concentrations of labile mutagenic and carcinogenic PAHs were observed at Bougival at both seasons, followed by Triel-sur-Seine, while Marnay-sur-Seine and StMaurice presented the lowest concentrations. The highest concentrations of PAHs were for Pyrene at St-Maurice (autumn), Bougival and Triel-sur-Seine and for Fluoranthene at Marnay-sur-Seine and St- 
234 mutagenic PAHs, had the highest concentrations at Bougival. No correlation was noted between PAHs 235 concentrations and Ames assay data (Spearman correlation).

\section{Discussion}

This study evaluated the coupling of mutagenicity bioassays and with LDPE membranes in evaluating

240 the genotoxicity of Seine River water. Investigation of the genotoxicity of water contaminants is 241 generally limited to dissolved contaminants collected after spot sampling (Houk, 1992; Umbuzeiro et 242 al., 2001) or to particulate contaminants which represent the greatest fraction of the hydrophobic 243 contaminants. Despite low genotoxicity, our data confirmed the predominance of direct and S9244 activated frameshift-type mutagens in surface water of the Seine River as frequently reported after 245 spot sampling (Ohe et al., 2004; Vincent-Hubert et al., 2012).

246 Mutagenic PAHs sampled with passive samplers may inform on the level of bioavailable compounds 247 to some aquatic organisms. However, the mutagenicity of bioavailable compounds is still difficult to 248 estimate probably for two main reasons, the very low concentration, compared with concentrations 249 usually used in standard genotoxicity assays, and the mixture of contaminants sampled with passive samplers. Very few studies have reported on the genotoxicity and the mutagenicity of river water contaminants collected with passive samplers even though their toxicity has been reported (Allan et al., 2012; Liscio et al., 2014). Gilli et al. reported that SPMD extracts from the Po River were not mutagenic (Gilli et al., 2005). Sabaliunas et al. tested the genotoxicity of river water in Lithuania with

254 SPMD coupled to the Mutatox assay and found a positive response only without S9 metabolic 255 activation, which indicated the presence of direct acting mutagens (Sabaliunas et al., 2000).

256 The low level of mutagenicity of LDPE extract in our study can be explained by the low concentration 257 of labile mutagenic PAHs, ranging from 13 to $126 \mathrm{ng} / \mathrm{LDPE}$ extract. For example for BaP, which is among 258 the more mutagenic PAHs, the highest concentration of $\mathrm{BaP}$ was 62 -fold below the lower $\mathrm{BaP}$ 
concentration reported positive in the Ames test ( $1 \mu \mathrm{g} /$ plate). Improvement of the detection could be

260 obtained in future studies by increasing the number of deployed membranes and the volume of sample

261 to be tested.

262 The concentrations of labile PAHs measured here are consistent with previous published data showing

263 that the Seine River sites under the influence of Paris area are more polluted than sites upstream of

264 Paris (Bourgeault and Gourlay-France, 2013; Michel et al., 2013).

265 The umu-assay is recognized as the most sensitive standard method for estimating the genotoxicity of

266 polluted waters such as industrial wastewater, suspended matter and surface water of rivers (Dizer et

267 al., 2002; Rao et al., 1995; Vahl et al., 1997). For the 2010 samples, the SOS induction gave a different

268 aspect of the genotoxicity than the Ames assay, as only one sample was positive in the Umu test

269 (Bougival) while all samples were mutagenic in the Ames assay (TA98+S9 mix). The umuC gene is

270 induced by DNA lesions but this does not lead necessarily to mutations which may explain the absence

271 of correlation between the two tests. The low reaction of the umu-test may be ascribed to the

272 presence of compounds that inhibit components of the SOS-system or the indicative enzyme, b-

273 galactosidase. The complexity of the mixtures makes the presence of SOS-inhibiting compounds

274 possible as reported in the literature (Vahl et al., 1997), even though the low concentration of PAHs

275 might be the major explanation of the low genotoxicity of LDPE extracts.

276

277 In conclusion, we developed a method for coupling the use of LDPE passive samplers with genotoxicity

278 assays. Field application of this new method revealed that labile dissolved PAHs extracted from passive

279 samplers were weakly positive with the TA98+S9 and Umu test. Concentrations of labile mutagenic

280 PAHs were higher upstream of Paris than downstream of Paris. Improvement of the method is needed

281 to determine the genotoxicity of low concentrations of labile dissolved organic contaminants. 
284 We thank Dr. Y. Oda (Japon) who gave the bacterial strain TA1535/pSK1002, Dr. B.N. Ames (Berkeley, 285 CA, USA) who gave the bacterial strains TA98 and TA100 and Dr T. Nohmi (Tokyo, Japan) who gave the 286 strain YG1041.

287 We thank R. LOUAILECHE and C. VARRET for technical assistance.

\section{Compliance with Ethical Standards}

Cécile MICHEL had a Ph.D. Grant from the lle-de-France Regional Council (R2DS program). This work

294 was supported by the PIREN- Seine research program.

297 performed by any of the authors.

\section{Figure legend:}

Figure 1: Localisation of the study sites in the Seine River Basin

Sampling sites on the Seine River are Marnay-sur-Seine, Bougival and Triel-sur-Seine. Saint-Maurice is on the Marne River.

Bougival and Triel sur Seine are subject to diffuse urban contamination of Paris city (Paris: $48^{\circ} 51^{\prime} 12^{\prime \prime}$ $\left.\mathrm{N}, 2^{\circ} 20^{\prime} 56^{\prime \prime} \mathrm{E}\right)$

$\triangle$ Seine-Aval wastewater treatment plant. 
313 Allan, S. E., Smith, B. W., Tanguay, R. L., and Anderson, K. A. (2012). Bridging environmental mixtures and toxic effects. Environmental Toxicology and Chemistry 31, 2877-2887. Blanchard, M., Teil, M. J., Guigon, E., Larcher-Tiphagne, K., Ollivon, D., Garban, B., and Chevreuil, M. (2007). Persistent toxic substance inputs to the river Seine basin (France) via atmospheric deposition and urban sludge application. Sci Total Environ 375, 232-243. Booij, K., Hofmans, H. E., Fischer, C. V., and Van Weerlee, E. M. (2003). Temperatureand low-density polyethylene membranes. Environmental Science \& Technology 37, 361-366. Bourgeault, A., and Gourlay-France, C. (2013). Monitoring PAH contamination in water: Comparison of biological and physico-chemical tools. Sci Total Environ 454, 328-336.

Cachot, J., Geffard, O., Augagneur, S., Lacroix, S., Le Menach, K., Peluhet, L., Couteau, J., Denier, X., Devier, M. H., Pottier, D., and Budzinski, H. (2006). Evidence of genotoxicity related to high PAH content of sediments in the upper part of the Seine estuary (Normandy, France). Aquat Toxicol 79, 257-267.

Carls, M. G., Holland, L. G., Short, J. W., Heintz, R. A., and Rice, S. D. (2004). Monitoring polynuclear aromatic hydrocarbons in aqueous environments with passive low-density polyethylene membrane devices. Environmental Toxicology and Chemistry 23, 1416-1424.

De Méo, M., Laget, M., Di Giorgio, C., Guiraud, H., Botta, A., Castegnaro, M., and Duménil, G. (1995). Optimization of the Salmonella/mammalian microsome assay for urine mutagenesis by experimental designs. Mutation Research - Reviews in Genetic Toxicology 340, 51-65.

Dizer, H., Wittekindt, E., Fischer, B., and Hansen, P. D. (2002). The cytotoxic and genotoxic potential of surface water and wastewater effluents as determined by bioluminescence, umuassays and selected biomarkers. Chemosphere 46, 225-233.

Gilli, G., Schiliro, T., Pignata, C., Traversi, D., Carraro, E., Baiocchi, C., Aigotti, R., Giacosa, D., and Fea, E. (2005). Application of semipermeable membrane device for assessing toxicity in drinking water. Chemosphere 61, 1691-1699.

Gourlay, C., Miege, C., Noir, A., Ravelet, C., Garric, J., and Mouchel, J. M. (2005). How accurately do semi-permeable membrane devices measure the bioavailability of polycyclic aromatic hydrocarbons to Daphnia magna? Chemosphere 61, 1734-1739.

Hagiwara, Y., Watanabe, M., Oda, Y., Sofuni, T., and Nohumi, T. (1993). Specificity and sensitivity of salmonella typhimurium YG1041 and YG1042 strains possessing elevated levels of both nitroreductase and acetyltransferase activity Mutat Res 291, 171-180.

Houk, V. S. (1992). The genotoxicity of industrial wastes and effluents: A review. Mutation Research - Reviews in Mutation Research 277, 91-138.

Kim, B. S., and Margolin, B. H. (1999). Statistical methods for the Ames Salmonella assay: a review. Mutation Research-Reviews in Mutation Research 436, 113-122.

Lebo, J. A., Zajicek, J. L., Huckins, J. N., Petty, J. D., and Peterman, P. H. (1992). Use of semipermeable membrane devices for in situ monitoring of polycyclic aromatic hydrocarbons in aquatic environments Chemosphere 25, 697-718.

Liscio, C., Abdul-Sada, A., Al-Salhi, R., Ramsey, M. H., and Hill, E. M. (2014). Methodology for profiling anti-androgen mixtures in river water using multiple passive samplers and bioassay-directed analyses. Water Research 57, 258-269.

Meybeck, M., Lestel, L., Bonte, P., Moilleron, R., Colin, J. L., Rousselot, O., Herve, D., de Ponteves, C., Grosbois, C., and Thevenot, D. R. (2007). Historical perspective of heavy metals contamination $(\mathrm{Cd}, \mathrm{Cr}, \mathrm{Cu}, \mathrm{Hg}, \mathrm{Pb}, \mathrm{Zn})$ in the Seine River basin (France) following a DPSIR approach (1950-2005). Sci Total Environ 375, 204-231. 
Michel, C., Bourgeault, A., Gourlay-France, C., Palais, F., Geffard, A., and Vincent-Hubert, F. (2013). Seasonal and PAH impact on DNA strand-break levels in gills of transplanted zebra mussels. Ecotoxicol Environ Saf 92, 18-26. Murahashi, T., Ito, M., Kizu, R., and Hayakawa, K. (2001). Determination of nitroarenes in precipitation collected in Kanazawa, Japan. Water Research 35, 3367-3372. Nikoyan, A., De Meo, M., Sari-Minodier, I., Chaspoul, F., Gallice, P., and Botta, A. (2007). Evaluation of a battery of Salmonella typhimurium tester strains for biomonitoring of mutagenic polycyclic aromatic hydrocarbons, nitroarenes and aromatic amines. Mutation Research - Genetic Toxicology and Environmental Mutagenesis 626, 88-101. Oda, Y., Funasaka, K., Kitano, M., Nakama, A., and Yoshikura, T. (2004). Use of a HighThroughput umu-Microplate Test System for Rapid Detection of Genotoxicity Produced by Mutagenic Carcinogens and Airborne Particulate Matter. Environ Mol Mutagen 43, 10-19.

Oda, Y., Nakamura, S. I., and Oki, I. (1985). Evaluation of the new sytem (umu-test) for the detection of environmental mutagens and carcinogens. Mutat Res 147, 219-229.

Ohe, T. (1996). Evaluation of SOS-inducing activity with an O-acetyltransferaseoverexpressing strain Salmonella typhimurium NM2009 for municipal river water and the identification of 1-nitropyrene. In Water Science and Technology, pp. 313-320.

Ohe, T., Watanabe, T., and Wakabayashi, K. (2004). Mutagens in surface waters: A review. Mutation Research - Reviews in Mutation Research 567, 109-149.

Rao, S. S., Burnison, B. K., Efler, S., Wittekindt, E., Hansen, P. D., and Rokosh, D. A. (1995). Assessment of genotoxic potential of pulp mill effluent and an effluent fraction using Ames mutagenicity and Umu-C genotoxicity assays. Environmental Toxicology and Water Quality 10, 301-305.

Sabaliunas, D., Ellington, J., and Sabaliuniene, I. (1999). Screening bioavailable hydrophobic toxicants in surface waters with semipermeable membrane devices: Role of inherent oleic acid in toxicity evaluations. Ecotoxicol Environ Saf 44, 160-167.

Sabaliunas, D., Lazutka, J. R., and Sabaliuniene, I. (2000). Acute toxicity and genotoxicity of aquatic hydrophobic pollutants sampled with semipermeable membrane devices. Environmental Pollution 109, 251-265.

Tusseau-Vuillemin, M. H., Gourlay, C., Lorgeoux, C., Mouchel, J. M., Buzier, R., Gilbin, R., Seidel, J. L., and Elbaz-Poulichet, F. (2007). Dissolved and bioavailable contaminants in the Seine river basin. Sci Total Environ 375, 244-256.

Umbuzeiro, G. D. A., Roubicek, D. A., Sanchez, P. S., and Sato, M. I. Z. (2001). The Salmonella mutagenicity assay in a surface water quality monitoring program based on a 20year survey. Mutation Research - Genetic Toxicology and Environmental Mutagenesis 491, 119-126.

Vahl, H. H., Karbe, L., and Westendorf, J. (1997). Genotoxicity assessment of suspended particulate matter in the Elbe river: comparison of Salmonella microsome test, arabinose resistance test, and umu-test. Mutation Research-Genetic Toxicology and Environmental Mutagenesis 394, 81-93.

Vincent-Hubert, F., Heas-Moisan, K., Munschy, C., and Tronczynski, J. (2012). Mutagenicity and genotoxicity of suspended particulate matter in the Seine river estuary. Mutation Research - Genetic Toxicology and Environmental Mutagenesis 741, 7-12.

Vrana, B., Mills, G. A., Allan, I. J., Dominiak, E., Svensson, K., Knutsson, J., Morrison, G., and Greenwood, R. (2005). Passive sampling techniques for monitoring pollutants in water. Trac-Trends in Analytical Chemistry 24, 845-868.

Wahrendorf, J., Mahon, G. A. T., and Schumacher, M. (1985). A non parametric approach to the statistical analysis of mutagenicity data Mutat Res 147, 5-13. 
407 Watanabe, M., Nohmi, T., and Ishidate, M. (1989). Establishment of new strains of S408 typhimurium highly sensitive to nitroarenes and amine aromatic- TA98 and TA100 derivatives 409 with high levels of nitroreductase or acetyltransferase activities Mutat Res 216, 383-383.

410

411

412 
Table 1: Genotoxicity and Mutagenicity of LDPE sampler deployed in the Seine River water in 2009

\begin{tabular}{|c|c|c|c|c|c|c|}
\hline \multirow[t]{2}{*}{ Sample } & \multirow[t]{2}{*}{ Dilution } & \multicolumn{2}{|c|}{$\begin{array}{c}\text { Umu test } \\
\text { (TA1535/pSK1002) }\end{array}$} & \multirow[t]{2}{*}{$\begin{array}{l}\text { Dose } \\
(\mu l)\end{array}$} & \multirow[t]{2}{*}{$\begin{array}{l}\text { Ames-test } \\
(\text { TA } 98+59)\end{array}$} & \multirow[t]{2}{*}{$\begin{array}{c}\text { Ames test } \\
\text { (YG 1041+S9) }\end{array}$} \\
\hline & & $-\mathrm{S9}$ mix & + S9 mix & & & \\
\hline & $1 / 8$ & $1.2 \pm 0.2$ & $1.4 \pm 0.1$ & 4 & $42 \pm 10$ & $120 \pm 24$ \\
\hline \multirow[t]{4}{*}{ Marnay } & $1 / 4$ & $1.3 \pm 0.2$ & $1.35 \pm 0.1$ & 6 & $51 \pm 6$ & $125 \pm 6$ \\
\hline & $1 / 2$ & $0.9 \pm 0.4$ & - & 8 & $61 \pm 7$ & nd \\
\hline & & & & 10 & $49 \pm 4$ & nd \\
\hline & $1 / 8$ & $1.21 \pm 0.2$ & $1.33 \pm 0.2$ & 4 & $29 \pm 4$ & $107 \pm 9$ \\
\hline \multirow[t]{3}{*}{ Bougival } & $1 / 4$ & $1.42 \pm 0.41$ & $1.33 \pm 0.2$ & 6 & $36 \pm 5$ & $100 \pm 4$ \\
\hline & $1 / 2$ & $0.94 \pm 0.33$ & - & 8 & $34 \pm 2$ & NC \\
\hline & & & - & 10 & $33 \pm 6$ & $97 \pm 11$ \\
\hline $\mathrm{BaP}$ & & & $1.97 \pm 0.4$ & & $654 \pm 8$ & $161 \pm 6$ \\
\hline DMSO 1\% & & $1.22 \pm 0.1$ & 1.1 & 10 & $31 \pm 6$ & $106 \pm 11$ \\
\hline LDPE control & & $0.94 \pm 0.5$ & $1.07 \pm 0.07$ & & $35 \pm 7$ & $130 \pm 24$ \\
\hline 4NQO & & $3.08 \pm 0.7$ & & & & \\
\hline 1-NP & & $2.11 \pm 0.4$ & & & & \\
\hline Control & & 1 & 1 & & & \\
\hline $\begin{array}{l}\text { Umu test: inc } \\
\text { Ames test: } n \\
\text { control value }\end{array}$ & $\begin{array}{l}\text { ion rate } \\
\text { per of re } \\
\text { MSO1\%). }\end{array}$ & $\begin{array}{l}\text { of } \beta \text { galactos } \\
\text { ertants/plat } \\
\text { Spontaneou }\end{array}$ & $\begin{array}{l}\text { ase activity } \\
\text { (mean } \pm \text { SD) } \\
\text { evertants: }\end{array}$ & $\begin{array}{l}\text { nean } \pm \\
\text { Bold fac } \\
\text { A98 }=25\end{array}$ & $\begin{array}{l}\text { Genotoxic sa } \\
\text { /alues are sig } \\
\text {; YG1048=111 }\end{array}$ & $\begin{array}{l}\text { value }>1.5 \\
\text { ly different from }\end{array}$ \\
\hline
\end{tabular}


Table 2: Genotoxicity and Mutagenicity of LDPE sampler deployed in the Seine River in 2010

\begin{tabular}{|c|c|c|c|c|c|c|}
\hline \multirow{2}{*}{ Sites } & \multirow{2}{*}{ Season } & \multirow[t]{2}{*}{$\begin{array}{c}\text { Umu test } \\
\text { (TA1535/pSK1002) }\end{array}$} & \multicolumn{2}{|c|}{$\begin{array}{c}\text { Ames test (TA 98) } \\
\text { (nb/rev/plate) }\end{array}$} & \multicolumn{2}{|c|}{$\begin{array}{l}\text { Ames test (TA100) } \\
\text { (nb rev/plate) }\end{array}$} \\
\hline & & & - S9 mix & + S9 mix & - S9 mix & + S9 mix \\
\hline \multirow[b]{2}{*}{$\begin{array}{l}\text { Marnay-sur- } \\
\text { Seine }\end{array}$} & Spring & $1.17 \pm 0.29$ & $12 \pm 5$ & $39 \pm 2$ & $110 \pm 7$ & $101 \pm 18$ \\
\hline & Autumn & $1.18 \pm 0.3$ & $96 \pm 8$ & $24 \pm 6$ & $77 \pm 18$ & $38 \pm 20$ \\
\hline \multirow{2}{*}{ St-Maurice } & Spring & $1.36 \pm 0.27$ & $27 \pm 2$ & $33 \pm 0.5$ & $121 \pm 13$ & $108 \pm 12$ \\
\hline & Autumn & $1.38 \pm 0.36$ & $164 \pm 89$ & $35 \pm 14$ & $81 \pm 8$ & $35 \pm 20$ \\
\hline \multirow{2}{*}{ Bougival } & Spring & $2.07 \pm 0.5$ & $17 \pm 7$ & $30 \pm 2$ & $142 \pm 15$ & $131 \pm 33$ \\
\hline & Autumn & $2.18 \pm 0.7$ & $14 \pm 2$ & $39 \pm 4$ & $82 \pm 2$ & $96 \pm 13$ \\
\hline \multirow{2}{*}{ Triel-sur-Seine } & Spring & $1.13 \pm 0.18$ & $16 \pm 4$ & $29 \pm 15$ & $125 \pm 2$ & $85 \pm 20$ \\
\hline & Autumn & $1.53 \pm 0.37$ & $12 \pm 3$ & $42 \pm 3$ & $118 \pm 22$ & $153 \pm 21$ \\
\hline DMSO 1\% & & 1.1 & $26 \pm 6$ & $10 \pm 1$ & $167 \pm 16$ & $127 \pm 9$ \\
\hline Positive control & & $7.85 \pm 2$ & $197 \pm 21$ & $371 \pm 181$ & $371 \pm 295$ & $1671 \pm 108$ \\
\hline $\begin{array}{l}\text { Spontaneous } \\
\text { revertants }\end{array}$ & & & $13 \pm 7$ & $11 \pm 0.5$ & $55 \pm 14$ & $95 \pm 30$ \\
\hline
\end{tabular}

Umu test: induction rate of $\beta$ galactosidase activity (mean \pm SD). Genotoxic sample $=$ value $>1.5$

Ames test: positive samples are two fold the DMSO value (bold letters). Control=DMSO1\%

Positive controls for Ames test were: $20 \mathrm{ng} / \mathrm{plate}$ 2,4,7-trinitrofluorenone for TA98-S9 mix and $5 \mu \mathrm{g} / \mathrm{plate}$ sodium azide for TA100-S9 mix. $0.5 \mathrm{and} 1 \mu \mathrm{g} / \mathrm{plate}$ of BaP for TA98 with S9 Mix. $10 \mu \mathrm{L}$ is the volume of LDPE extract tested with the Ames assay. Mean of three replicates. 
Table 3: Concentrations of Labile PAHs in LDPE

\begin{tabular}{|c|c|c|c|c|c|c|c|}
\hline \multirow[t]{2}{*}{$\begin{array}{c}\text { PAHs } \\
\text { (ng/LDPE extract) }\end{array}$} & \multicolumn{2}{|l|}{$\begin{array}{c}\text { Marnay sur } \\
\text { Seine }\end{array}$} & \multicolumn{2}{|c|}{ St-Maurice } & \multicolumn{2}{|c|}{ Bougival } & \multirow{2}{*}{$\begin{array}{c}\text { Triel sur Seine } \\
\text { Spring } \\
\end{array}$} \\
\hline & Spring & Autumn & Spring & Autumn & Spring & Autumn & \\
\hline Acenaphtene & 0.42 & 0.89 & 0.53 & 0.57 & 2.41 & 2.09 & 1.42 \\
\hline Fluorene & 0.65 & 1.37 & 1.07 & 0.85 & 2.63 & 2.02 & 2.06 \\
\hline Phenanthrene & 2.20 & 4.03 & 3.00 & 2.23 & 8.66 & 6.43 & 6.84 \\
\hline Anthracene & 0.59 & 0.96 & 1.06 & 1.86 & 5.08 & 6.24 & 2.77 \\
\hline Fluoranthene & 5.04 & 8.36 & 6.56 & 4.39 & 21.20 & 13.64 & 18.77 \\
\hline Pyrene & 1.99 & 4.62 & 6.00 & 7.18 & 31.05 & 28.14 & 27.52 \\
\hline Benzo(a)anthracene & 0.10 & 0.34 & 1.01 & 0.43 & 5.52 & 4.93 & 5.32 \\
\hline Chrysene & 0.46 & 0.78 & 1.72 & 1.75 & 6.93 & 4.71 & 6.83 \\
\hline Benzo(b)fluoranthene & 1.03 & 2.33 & 1.84 & 4.35 & 13.05 & 21.04 & 4.42 \\
\hline Benzo(k)fluoranthene & 0.27 & 0.50 & 1.05 & 1.42 & 4.97 & 8.73 & 1.98 \\
\hline Benzo(a)pyrene & 0.24 & 0.56 & 0.80 & 1.37 & 9.09 & 16.04 & 2.58 \\
\hline Indeno(1.2.3-cd)pyrene & 0.43 & 0.72 & 0.81 & 1.06 & 3.05 & 5.77 & 0.84 \\
\hline Dibenz(a.h)anthracene & 0.08 & 0.24 & 0.22 & 0.49 & 1.19 & 1.68 & 0.51 \\
\hline Benzo(g.h.i)perylene & 0.34 & 0.65 & 0.57 & 1.19 & 3.13 & 4.87 & 1.39 \\
\hline$\Sigma \mathrm{PAHs}$ & 13.88 & 26.41 & 26.29 & 29.22 & 118.02 & 126.40 & 83.31 \\
\hline labile mutagenic PAHs & 24.86 & 22.45 & 22.81 & 24.86 & 104.83 & 110.26 & 76.20 \\
\hline labile carcinogenic PAHs & 2.63 & 5.50 & 7.47 & 10.92 & 43.83 & 62.93 & 22.49 \\
\hline
\end{tabular}

Sum of mutagenic PAHs: phenanthrene. pyrene. fluoranthene. benzo(a)anthracene. chrysene. benzo(b)fluoranthene. benzo(k)fluoranthene. benzo(a)pyrene. dibenz(a.h)anthracene. benzo(g.h.i)perylene.

Sum of the PAHs classified as probable human carcinogens according to the U.S. EPA classification. The PAHs included in this calculation belong to groups

1. 2B and 2A: benzo[a]anthracene (BaA). benzo[a]pyrene (BaP). benzo[b]fluoranthene (BbF). benzo[k]fluoranthene (BkF). chrysene (CHRY).

dibenz[a.h]anthracene (DBahA). and indeno[1.2.3-c.d]pyrene (I123cdP). 


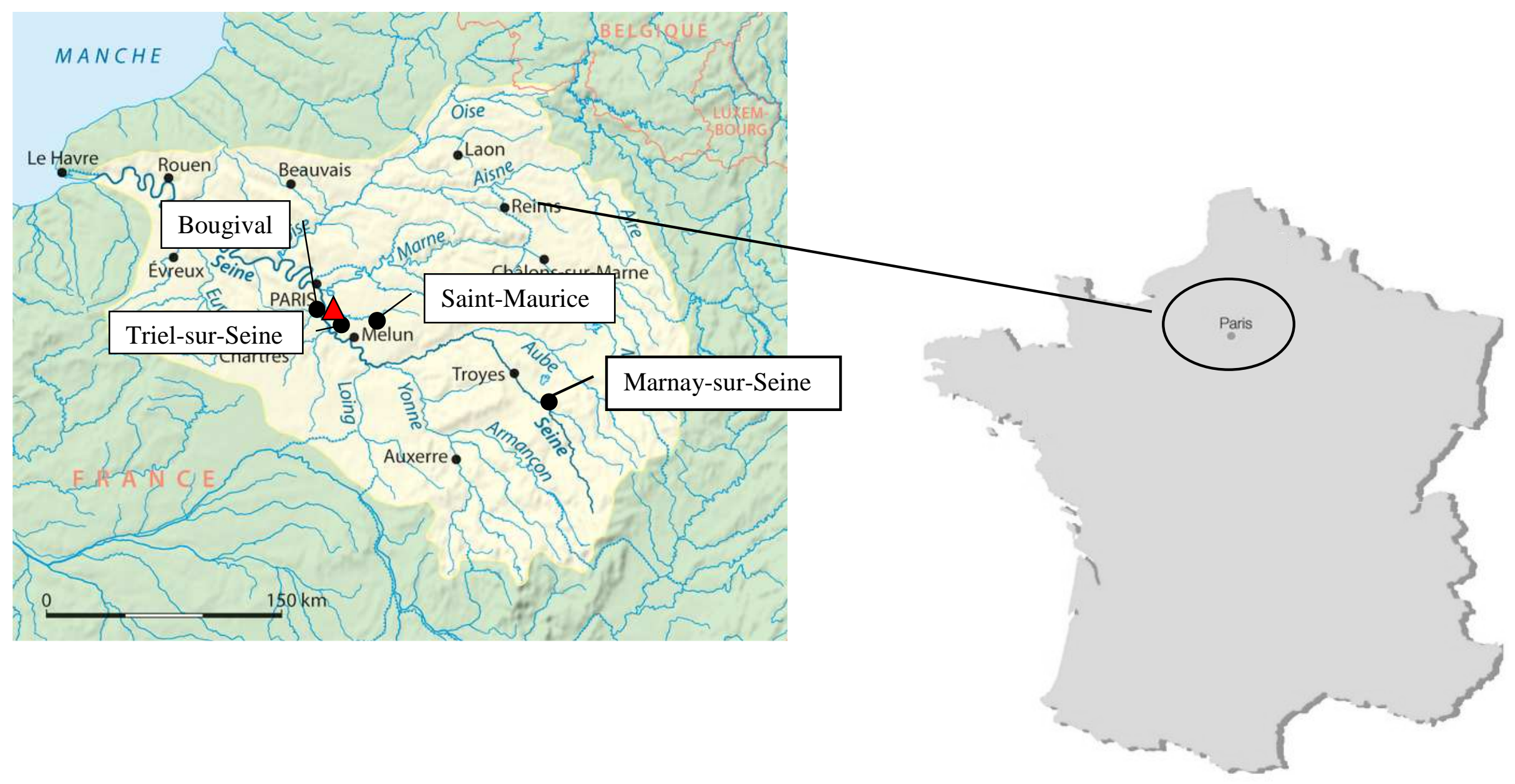

